\title{
LEVEL OF STRESS AMONG CAREGIVERS OF CANCER PATIENTS UNDERGOING CHEMOTHERAPY
}

Dr. Mandeep Kaur* \& Ms. Kiranjit Kaur**

*Associate Professor, CKD International Nursing College, Amritsar, Punjab, India.

**Assistant Professor, CKD International Nursing College, Amritsar, Punjab, India. DOI: http://doi.org/10.47211/idcij.2020.v07i03.011

Received $5^{\text {th }}$ June 2020, Accepted $20^{\text {th }}$ June 2020, Available online $10^{\text {th }}$ July 2020.

\section{ABSTRACT:}

Cancer is a group of more than 200 diseases characterised by uncontrolled and unregulated growth of cells. Cancer is the second most common cause of death. Globally, it is estimated that there are 7.6 million new cancer cases, of which 52\% occurs in developing countries. A caregiver is someone who provides physical and emotional care to the person suffering with an illness. As the number of cancer cases increases, the number of care givers also increased. The health of the caregivers and cancer patients are interdependent.

A descriptive study conducted on 60 cancer patient caregivers on chemotherapy, of age group 20-50, in chemotherapy department of GND Hospital, Amritsar to assess the level of stress among them. For this study, purposive sampling techniques were used to select sample and self-structured questionnaire was used for collecting data.

The study revealed that majority $78.3 \%$ people suffer from moderate stress; besides only $11.6 \%$ and $10 \%$ people suffer from mild and severe level of stress respectively. So there is a need to provide education regarding stress relieving and coping measures to the family members.

KEYWORDS: Cancer patients, chemotherapy, stress among caregivers.

ABOUT AUTHORS:

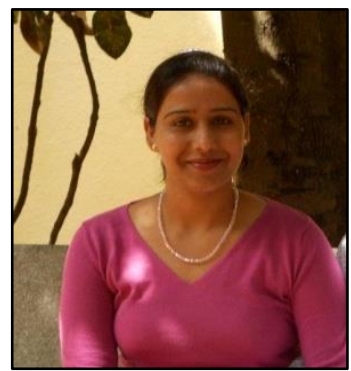

Author Dr. Mandeep Kaur is Associate Professor, CKD International Nursing College, Amritsar, Punjab, India. She is active researcher and has attended various Seminars and conferences.

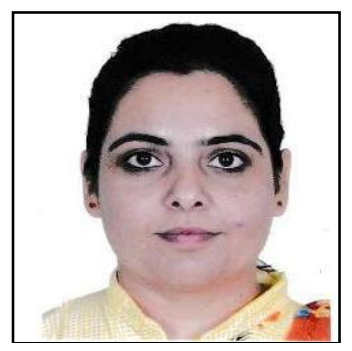

Author Ms. Kiranjit Kaur is Assistant Professor, CKD International Nursing College, Amritsar, Punjab, India. She has published various research articles in National and International Journals. 


\section{ARTICLES}

A caregiver is someone who provides physical and emotional care to the person suffering with an illness.

In many cases caregivers are family members, often spouses, parents or children or close friends, providing care to family members can be positive and rewarding experience. The role can be stressful with often overwhelming physical emotional and financial demands. At some point in life every individual becomes a caregiver Dorothy R Marlow (2012).

Globally it is estimated that there are 7.6 million new cancer cases, of which $52 \%$ occurs in developing countries. The magnitude of problems of cancer in the Indian subcontinent in terms of sheer number is most alarming. There is predicted sharp increase in new cases from 10 million in 2000 to 15 million in 2020 in developing and developed countries.

\section{NEED OF THE STUDY:}

Cancer is a group of more than 200 diseases characterised by uncontrolled and unregulated growth of cells. Cancer is the second most common cause of death. In India, every year about 8, 50,000 new cancer cases are diagnosed resulting in about 5, 80,000 cancer related deaths every year. In males oral, lungs, stomach cancers are most common causes of cancer incidence and death. As the number of cancer cases increases, the number of care givers also increased. The health of the caregivers and cancer patients are interdependent.

According to Seguin and Bonham (2006), there is a high concordance between the patients' and the care givers' emotional distress. The caregivers often experience higher distress than the cancer patients. Studies have shown that many care givers are available in the hospital with the patients to care them but still they do not have the adequate knowledge and positive attitude in providing the care. It is important for the care givers to learn and understand the importance of those care and needs, which are essential for the patients to be provided. They can clarify these doubts from the nurse so that they can reach the expectations of the patients.

In the light of above fact and personal experience of the investigator as a staff in the clinical area while assessing the knowledge and attitude of caregivers, it was observed that most of the caregivers had lack of knowledge and favourable attitude in meeting the physiological needs of cancer patients . Hence the research was interested in the above area and wanted to impact knowledge and attitude of caregivers regarding meeting the physiological needs of patients with cancers.

PROBLEM STATEMENT:- 


\section{ARTICLES}

A descriptive study to assess the level of stress among care givers of cancer patient in Chemotherapy department of Guru Nanak Dev Hospital, Amritsar Punjab.

\section{OBJECTIVES:}

a. To assess the stress level among care givers of cancer patient

b. To assess the association of stress level among care givers of cancer patient with selected sociodemographic variables.

c. To prepare and distributed an information booklet on stress level.

\section{CONCEPTUAL FRAMEWORK:}

Lazarus and Folk man's Transactional Stress Theory provided the theoretical framework for this research (Lazarus \& Folk man, 1984).

Lazarus and Folk man's Transactional Stress Theory has been used extensively in stress, burden, and coping research. The Transactional Stress Theory suggested that the individual and environment interact in a dynamic and mutually shared relationship. Stress occurs when the interaction between the person and the environment taxes the person's coping resources and threatens his or her physical and psychological well-being.

\section{METHODS AND MATERIAL:}

The research approach for this study was descriptive, conducted in a chemotherapy Department at GNDH among 60 caregivers selected aged between 20 to 50 years, selected using purposive sampling technique.

The tool consisted of two sections: Section A: selected socio-demographic variables \& Section B: Self structured questionnaire.

Procedure of data collection: The investigator took permission from the MEDICAL OFFICER of the Guru Nanak Dev Hospital, Amritsar to carry out research study

\section{ETHICAL CONSIDERATIONS}

1. Written permission took from principal of Chief Khalsa Diwan international college of Nursing, Chabhal Road, Amritsar.

2. Written permission was taken from higher authority of the chemotherapy department to conduct the research study.

3. Written Consent from study subjects.

RESULTS: 
SECTION I

Table No. 1

Frequency and percentage distribution of sample characteristics.

$\mathrm{N}=60$

\begin{tabular}{|c|c|c|c|c|c|c|}
\hline Sr. & $\begin{array}{l}\text { Socio Demographic } \\
\text { variable }\end{array}$ & uency (n) & entage (\%) & Mild & Moderate & Severe \\
\hline \multirow[t]{5}{*}{1.} & Family Age & & & & & \\
\hline & $20-30$ & 17 & $28.3 \%$ & 03 & 11 & 02 \\
\hline & $31-40$ & 08 & $13.3 \%$ & 01 & 07 & 02 \\
\hline & $41-50$ & 18 & $30 \%$ & 00 & 17 & 01 \\
\hline & Above 50 & 17 & $28.3 \%$ & 02 & 12 & 02 \\
\hline \multirow[t]{3}{*}{2.} & Gender & & & & & \\
\hline & Male & 37 & $61.6 \%$ & 05 & 30 & 03 \\
\hline & Female & 23 & $38.3 \%$ & 01 & 17 & 04 \\
\hline \multirow[t]{4}{*}{3.} & Marital Status & & & & & \\
\hline & Married & 43 & $71.6 \%$ & 05 & 34 & 04 \\
\hline & Unmarried & 15 & $25 \%$ & 01 & 11 & 02 \\
\hline & Divorced & 02 & $3.3 \%$ & 00 & 02 & 01 \\
\hline \multirow[t]{3}{*}{4.} & Type of Family & & & & & \\
\hline & Nuclear & 35 & $58.3 \%$ & 04 & 29 & 04 \\
\hline & Joint & 25 & $41.6 \%$ & 02 & 18 & 03 \\
\hline \multirow[t]{5}{*}{5.} & Occupation & & & & & \\
\hline & Employed & 37 & $61.6 \%$ & 04 & 28 & 05 \\
\hline & Unemployed & 10 & $16.6 \%$ & 0 & 10 & 0 \\
\hline & Retired & 05 & $8.3 \%$ & 0 & 04 & 0 \\
\hline & Housewife & 08 & $13.3 \%$ & 02 & 05 & 02 \\
\hline \multirow[t]{3}{*}{6.} & $\begin{array}{l}\text { Relation with } \\
\text { patient }\end{array}$ & & & & & \\
\hline & Son & 15 & $25 \%$ & 1 & 12 & 02 \\
\hline & Daughter & 05 & $8.3 \%$ & 1 & 4 & 0 \\
\hline
\end{tabular}

Table No. 1:- Reveals $28.37 \% ; 13.3 \% ; 30 \%$, and $28.3 \%$ of caregivers belonged to age group $20-30 ; 31-40 ; 41-$ 50 and above 50, respectively. Majority of them were married (25\%) and males (61.6\%). Almost, equal proportion of caregivers belonging to both joint and nuclear families. Largely, caregivers were spouses of the patients and were working. However, the as per educational status, around half were illiterate. $81.6 \%$ always accompanied the patients. 
Table No. 2

Frequency and \% distribution of stress level regarding caregiver of cancer patients.

Frequency and \% distribution of stress level regarding caregiver of cancer patients.
\begin{tabular}{|l|c|c|}
\hline Level of Stress & Frequency (N) & Percentage (\%) \\
\hline Mild & 06 & $10 \%$ \\
\hline Moderate & 47 & $78.3 \%$ \\
\hline Severe & 07 & $11.6 \%$ \\
\hline
\end{tabular}

Maximum Score $=20$ Minimum Score $=0$

Table No. 2 depicts that the 78.3\%, 11.6\%, and 10\% caregivers had Moderate, severe, and mild level of stress.

SECTION -III

Table No. 3

Chi-Square, Df and P-Value of sample characteristics.

\begin{tabular}{|c|c|c|c|c|c|c|c|}
\hline Sr. & $\begin{array}{l}\text { Socio Demographic } \\
\text { variable }\end{array}$ & Mild & Moderate & Severe & $\begin{array}{c}\text { Chi- } \\
\text { square }\end{array}$ & $\mathrm{df}$ & $p$-value \\
\hline \multirow[t]{5}{*}{1.} & Family Age & & & & & & \\
\hline & $20-30$ & 03 & 11 & 02 & \multirow[t]{4}{*}{5.211} & \multirow[t]{4}{*}{6} & \multirow[t]{4}{*}{0.517} \\
\hline & $31-40$ & 01 & 07 & 02 & & & \\
\hline & $41-50$ & 00 & 17 & 01 & & & \\
\hline & Above 50 & 02 & 12 & 02 & & & \\
\hline \multirow[t]{3}{*}{2.} & Gender & & & & & & \\
\hline & Male & 05 & 30 & 03 & \multirow[t]{2}{*}{2.302} & \multirow[t]{2}{*}{2} & \multirow[t]{2}{*}{0.3163} \\
\hline & Female & 01 & 17 & 04 & & & \\
\hline \multirow[t]{4}{*}{3.} & Marital Status & & & & & & \\
\hline & Married & 05 & 34 & 04 & \multirow[t]{3}{*}{2.079} & \multirow[t]{3}{*}{4} & \multirow[t]{3}{*}{0.7212} \\
\hline & Unmarried & 01 & 11 & 02 & & & \\
\hline & Divorced & 00 & 02 & 01 & & & \\
\hline \multirow[t]{3}{*}{4.} & Type of Family & & & & & & \\
\hline & Nuclear & 04 & 29 & 04 & \multirow[t]{2}{*}{0.124} & \multirow[t]{2}{*}{2} & \multirow[t]{2}{*}{0.9398} \\
\hline & Joint & 02 & 18 & 03 & & & \\
\hline \multirow[t]{5}{*}{5.} & Occupation & & & & & & \\
\hline & Employed & 04 & 28 & 05 & \multirow[t]{4}{*}{3.101} & \multirow[t]{4}{*}{4} & \multirow[t]{4}{*}{0.5410} \\
\hline & Unemployed & 0 & 10 & 0 & & & \\
\hline & Retired & 0 & 04 & 0 & & & \\
\hline & Housewife & 02 & 05 & 02 & & & \\
\hline \multirow[t]{5}{*}{6.} & $\begin{array}{l}\text { Relation with } \\
\text { patient }\end{array}$ & & & & & & \\
\hline & Son & 1 & 12 & 02 & \multirow[t]{4}{*}{4.094} & \multirow[t]{4}{*}{6} & \multirow[t]{4}{*}{0.6690} \\
\hline & Daughter & 1 & 4 & 0 & & & \\
\hline & Spouse & 1 & 21 & 03 & & & \\
\hline & Other & 3 & 10 & 02 & & & \\
\hline \multirow[t]{5}{*}{7.} & Education & & & & & & \\
\hline & Illiterate & 1 & 23 & 04 & \multirow[t]{4}{*}{4.617} & \multirow[t]{4}{*}{6} & \multirow[t]{4}{*}{0.5938} \\
\hline & Primary & 4 & 21 & 02 & & & \\
\hline & Graduation & 1 & 2 & 01 & & & \\
\hline & Post Graduation & 0 & 1 & 0 & & & \\
\hline 8. & $\begin{array}{l}\text { Accompanying } \\
\text { with patient }\end{array}$ & & & & & & \\
\hline & Yes & 3 & 34 & 06 & 3.578 & 4 & 0.4661 \\
\hline & No & 0 & 03 & 0 & & & \\
\hline & Some Time & 3 & 10 & 01 & & & \\
\hline
\end{tabular}


Table 3: shows that there is no significant association between level of stress and socio demographic variables under the study.

\section{DISCUSSION:}

The baseline stress level among caregiver of cancer patient revealed that out of 60 caregivers. It is evident that 78. $3 \%$ caregivers having moderate stress, $11.6 \%$ caregiver having severe stress and $10 \%$ caregivers having mild stress. According to OLI (2014) revealed their study that most of the care givers having severe stress rather than cancer patient. It was found in the present study that caregivers in the age group of above 50 and males had highest stress level. According to TESCHENDERF ETAL (2007) revealed that more stress among the age of above 41 in $87 \%$ male having stress rather than female.

\section{CONCLUSION:}

Mainly of caregivers belonged to age groups of 20-30 and above 50. Majority of them were married (25\%) and males (61.6\%). Almost, equal proportion of caregivers belonging to both joint and nuclear families. Largely, caregivers were spouses of the patients and were working. However, the as per educational status, around half were illiterate. $81.6 \%$ always accompanied the patients. Results reveal that majority caregivers suffered moderate levels of stress. There was no significant association found between level of stess and socio demographic variables.

\section{REFERENCES}

1. Dorothy R Marlow, Barbara A. Redding. Text Book of Pediatric Nursing. $6^{\text {th }}$ ed. New Delhi: Harcourt India Pvt. Ltd; 2001; 20.

2. National cancer institute, kidwai memorial institute of technology. SEER cancer statistics. Available at http: seer. Cancer. Gov.Acessed 2006Jan 31;

3. Joyce M Black Esther Mataserin Jacob. Medical Surgical Nursing. Clinical Management for Continuity of care. $5^{\text {th }}$ ed. New Delhi: Harcourt Brace and company.

4. B. A. Given, C.W. Given, Sharon Kozachik. Family Support in Advanced Cancer. American Cancer Society. CA Cancer J. Clin 2001; 51:213.

5. WHO, cancer statistic. GENEVA; 2002; 4-6. Parking DM, Bray F, Pisani P. Global cancer statistics; 2002; 74184.

6. Dr k Ramchandra Reddy, Dr PP Basy. Population based cancer registry. Kidwai memorial institute of oncology. BangaloreNRCP. Indian council of Medical Research; 2002; 10-12.

7. Mellon S, Northouse LL, Weiss LK. A population based study of the quality of life of cancer survivors and their family caregivers. Cancer Nurs. 2006 Mar - Apr; 29(2); 120-31.

8. Hauser JM Chang $\mathrm{CH}$, Alpret $\mathrm{H}$, Baldwin D, Emanuel EJ, Emanuel L. who is caring for whom? Differing perspectives between seriously ill patients and their family caregivers'. AM J Hosp Palliate care. 2006MarApr; 23(2):105-12.

9. J, Marisett S, Williams D, Nyhof-young J, Crooks D, Husain A, etal. Decision making in palliative radiation therapy: reframing hope in caregivers and patients with metastasis. Support care cancer 2006 Oct; 14 (10):1055-63.

10. Schumacher KL, Stewart BJ, Arch bold PG. Mutuality and preparedness moderate the effects of care giving demand on cancer family caregiver outcomes. Nurs res. 2007 Nov- Dec; 56 (6):425- 33.

11. Marion F. Winkler, Vicki M. Ross, Ubolrat Piamjariyakul, Byron Gajewski, Carol E. Smith. Technology Dependence in Home Care: Impact on Patients and Their Family Caregivers. Available from www.google.com/.

12. Ruth Vortherms, Patrick Ryan, Dr. Sandra Ward. Knowledge of attitudes toward, and barriers to pharmacologic management of cancer pain in a statewide random sample of nurses. 1992 May; Available from www. Google.com/. 